\title{
A Sard Intaglio with a Depiction of Priapus from the Acropolis of Olba
}

\author{
Yavuz YEĞİN* - Bruna NARDELLI**
}

\section{Introduction}

Archaeological excavations have been conducted since 2010 in the city of Olba, a settlement in the Silifke District of Mersin, and produced important new information about the history of the city in antiquity. Stone tools (obsidian, flint) recovered from the acropolis and the surrounding valley point to traces of prehistoric inhabitation. On the other hand, the discovery of sherds of red-brown hand-made coarse ware with scored linear motifs on the Acropolis have taken the history of the settlement to the Late Chalcolithic-Early Bronze Age. Similar 'scored ware' ceramics have been found in centers such as Kilisetepe, Mersin Yumuktepe and Tarsus Gözlükule.

Another early find from the Olba Acropolis (fig.1) is a chalcedony stamp seal in pyramidal form dating to the 6th century BC, which reflects Olba's connections with Neo-Babylonian culture in Mesopotamia. While the relations of the region with Mesopotamia in the Iron Age were already known from written sources, the seal provides material evidence exemplifying the connection ${ }^{1}$. Moreover, there is numismatic evidence suggesting an Achaemenid presence in the city, extending into the Macedonian period after $333 \mathrm{BC}$. The excavations have also provided important new information about the Hellenistic fortification system of the Acropolis ${ }^{2}$. It is however the small finds from this area that shed light on the earlier phases of the city ${ }^{3}$.

The ring stone that is the subject of this paper was recovered during the 2018 season in the course of work carried out in trench $10 .{ }^{4}$ It was found at a depth of $-10 \mathrm{~cm}$ inside a tomb oriented eastwest and surrounded by rows of stones. During cleaning work carried out in the tomb, skeletal fragments of a torso, thought to be that of a small child, were encountered. Additional finds apart from the gem include sherds of ceramic and glass and some corroded metal artefacts.

We propose here to analyse the gem fragment primarily in terms of its iconography and its historical characteristics. We discuss the figure itself in terms of its composition and stylistics, concluding with comments and suggestions regarding the purpose and dating of the ring-stone.

*Dr. Yavuz Yeğin, Ardahan University Department of Archaeology, Ardahan (yavuz.yegin002@ gmail. com; (D) https://orcid.org/0000-0001-7901-6352).

${ }^{* *}$ Bruna Nardelli, University of Ca'Foscari Venezia, Italy (bunanarvenezia@gmail.com; (D) https://orcid. org/0000-0003-1167-963X).

The excavations in Olba began in 2010 under the direction of Professor Dr. A. Emel Erten and are still continuing. We are extremely grateful to Prof. Dr. A. Emel Eaten for giving us permission to publish the gem under discussion here.

${ }^{1}$ For detailed information about the New Babylonian seal from the Acropolis, see Erten 2018, 49-69.

${ }^{2}$ Erten 2017, 129-146.

${ }^{3}$ For the glass finds, see Erten - Akkuş-Koçak 2019, 43-63; Erten 2019, 331-344; For the other small finds, see Erten 2021, 33-48.

${ }^{4}$ The identifier is "Gem/Acropolis Zirve Sounding 10". 


\section{Evaluation of the iconography of the gem found on the Acropolis of Olba}

During the 2018 excavation campaign at Olba an engraved gem (figs. 2-3) was recovered that in one important respect makes a valuable contribution to the study of engraved gems. As a rule, the discovery of gems within a specific context is of significant documentary value because it helps us unpack one of the most complex issues in glyptic studies, namely the authenticity and historical context of semi-precious ancient gems kept in public and private collections ${ }^{5}$. As is well known, the provenience of the majority of gems discovered in Turkey is unrecorded; in many cases we do not even know where they were found (i.e. their provenance), or in what circumstances ${ }^{6}$. The discovery of the intaglio during the course of a documented excavation is thus a welcome exception to the lack of such information about the great majority of gems held in public ${ }^{7}$ and private $^{8}$ collections in Turkey and elsewhere ${ }^{9}$.

The sard intaglio ${ }^{10}$ found in a child's grave can be only partially assessed because the upper part of the stone is missing. However, one can clearly make out the left-facing profile of a naked male figure, clasping his phallus clasped in his hands. The lower part of his body features long, sturdy legs, and large feet planted on a ground line.

The fragmentary condition of the piece means it is difficult to identify the subject with complete confidence (fig. 4). Traces at the top might suggest a more complex design: given the modelling of the lower part of the nude body and the oversized depiction of the male genitalia, we cannot rule out the possibility that it portrays a figure associated with Dionysiac worship, of the kind regularly found in ancient glyptic production ${ }^{11}$. Nevertheless, the iconographic clues - the powerfully muscular anatomy of the lower part of the nude body and the enlarged phallus -

\footnotetext{
${ }^{5}$ On collecting: Tassinari 2011, 138-140. On the importance of gems discovered during archaeological excavation: Tassinari 2011, 143-145.

${ }^{6}$ Little information is available about gems found during Turkish excavations: Tassinari 2008, 280-281, 284-285; Weiss 2013. We are grateful to Dr. Mehmet Önal and Dr. Ergün Laflı for information about such gems. It is worth pointing out that more than 100,000 clay seal impressions have been found during the recovery excavations at Zeugma, but not a single gem: Önal 2007; Önal 2010; Önal 2011; Sayar - Önal (in press).

${ }^{7}$ Important glyptic collections are held in the Museum of Anatolian Civilisation (Bingöl 1999, 77, 147, 155-157, 160, 165, 166) and in the museums of Izmir: Lafl1 2012.

${ }^{8}$ Numerous gems are kept in private collections in Turkey, and thus largely lost to scholarship. One exception is the Yüksel Erimtan Collection (consisting of 180 nice pieces): Konuk - Arslan 2000. Dssa Nardelli would like to thank Mr. Erimtan for allowing her to inspect it herself.

${ }^{9}$ A large number of gems from Turkey are held in European museums: Vienna: AGWien I, 77, 38, nos. 21, 164; Munich: AGDS I,1, 62, no. 302; AGDS I,2, 62, 76, nos. 911, 1004; AGDS I,3; 15, 20, 26, 35, 56, 58, $108,112,118,126$, nos. 2179, 2212, 2252, 2305, 2444, 2449, 2829, 2859, 2892, 2937, pl. 189, 193, 197, 205, 221, 222, 267, 271, 276, 286. Numerous cameos are kept in the Ashmolean Museum: Henig 1990, 12, 18, 20, $53,60,62,78,82,86,99$, nos. 12-22, 32, 36, 83, 87, 101, 105, 106, 140, 145, 149, 154,172; as well as in the Wright Collection: Hoey Middleton 2001, 106, 140, 145, 149, 154,172. There are 72 gems in the Paul Getty Museum: Spier 1992.

${ }^{10}$ GEM.AZ.10.1. Chalcedony-sard. Dim. mm: 12,0 x 12,0; Weight: 0.89 gr. The upper part of the stone is missing.

${ }^{11}$ For example, the intaglio with ithyphallic Satyr kept at The Hague: Maaskant-Kleibrink 1978, 104, n. 81, pl. 18 (agate), or the ithyphallic herms: Maaskant-Kleibrink 1978, 156-7, nos. 274-275, pl. 54 (banded agate).
} 
suggest a Priapus (Gr. Priapos). The intaglio presumably follows a specific typological format based on statuary models, such as the example from Sousse (Hadrumetum) now in the Archaeological Museum of Tunis ${ }^{12}$. If so, we may take it that the lost part of the design followed a standard pattern, namely a bearded god wearing a tunic or mantle whose upper folds contain fruit.

Priapus, the rustic fertility god originally from Lampsacus in Asia Minor (Turkey) ${ }^{13}$, was a popular subject in ancient Greek and Roman glyptic production. A variety of different designs is known. The Olba intaglio is distinguished by iconographic and stylistic characteristics rarely found in gems in other known collections, and by its meticulous workmanship. Its most remarkable feature, however, is its perfect formal balance, making it a very significant find in terms of iconography and stylistic features, taking into account the treatment of the anatomical form and the emphatically-moulded muscles which highlight the beauty of the male body. The piece includes iconographic and stylistic details that set it apart from known formats and might suggest the existence of an iconographic variant of a familiar theme that has not hitherto been seen in gems from other collections. In fact, there seem to be no direct iconographic parallels or stylistic and gemmological similarities between the Olba piece and intaglios belonging to known public and private collections. However, there is an iconographic parallel in a glass intaglio in the British Museum with specific reference to the position of the legs and, in particular, the treatment of the 'pellets' 1 .

A number of glyptic collections own intaglios showing Priapus with variations in iconography, technical and artistic skill, such as a hematite in Hannover ${ }^{15}$, or a number of magnificent sards in the British Museum showing Priapus holding objects that are consecrated to him ${ }^{16}$. Unlike other known examples of the type, the Olba intaglio has a distinctive structure, especially in the modelling of the body, but also because of the movement suggested by the position of the legs. The confident design and skilfully modelled parts of the body, the considerable formal rigour combining classical style with the simplified rendering of the knees and feet by means of stippling ("pellet style") ${ }^{17}$, are typical features of Italic-Republican glyptic production. The compositional style and the use of the round drill allow the sard to be dated to the second century BC.

The theme of Priapus, originating in the Greek world and adopted by the Romans, bears witness to the popularity of this figure in glyptic production across the Empire, as evidenced by the many examples found in nearly all known collections. The evolution of the theme is apparent in iconographic representations of Priapus as he falls in status from god of nature to rural divinity ${ }^{18}$.

12 della Ratta-Rinaldi 1995, fig. 5.

${ }^{13}$ Martini 1981; Ceci 1995.

${ }^{14}$ Walters 1927, 289, n. 3022 (green glass).

${ }^{15}$ AGDS IV, Hannover, 179, n. 889, pl. 115.

${ }^{16}$ Walters 1927, 178, n. 1651 (holding three ears of corn and three poppies); nos.1652, 1553 (with sickle in r. hand).

${ }^{17}$ For the so-called "pellet style" (in which details are rendered as tiny pin-heads or 'rivets') in ItalicRepublican flat-stone glyptic production, see Maaskant - Kleibrink 1978, 131,132.

${ }^{18}$ The cult was associated with agriculture, protection of flocks, orchards and fish-ponds: Z Knight 1981, 9, 100-103. 
Gems showing the ithyphallic, bearded version of Priapus standing in profile, muscles now barely outlined, appear regularly in various public collections ${ }^{19}$. Another device commonly found in ancient glyptic production is that of the herm of Priapus ${ }^{20}$, but complex priapic scenes, an outdoor rustic sacrifice in honour of Priapus, are the most frequent figural theme. As R. Fellman Brogli has pointed out, several iconographic groups with a number of variants have been identified ${ }^{21}$. Two gems in Turkish collections - an agate in the Erimtan collection and an intaglio in the Archaeological Museum of Izmir - are interesting examples ${ }^{22}$.

How the gem from Olba was used is a complex and largely hypothetical question. As an item of personal jewellery, set in a mount, it could have been used as a personal seal: perhaps it belonged to the person buried in the grave ${ }^{23}$. As a religious offering, the gem may have been a distinctive devotional sign, possibly with ritual associations. At all events the ring is to be seen as an object reflecting a personal affinity of some sort, possibly to the cult of Dionysus, but more likely evoking Priapus's relationship with abundance - or, if the grave was that of a child, with apotropaic force.

There is finally the question - and it is one of the most complex in the field of glyptic studies - as to the origin of the gem: that is, whether it was imported or locally made, depending on whether there were intaglio workshops in the area $^{24}$. To date, not all relevant evidence has been made available to scholars ${ }^{25}$, and the absence of a thorough overview of engraved gems of Turkish origin makes this a difficult question to answer ${ }^{26}$. It should also be noted that few sites in Turkey offer starting points for research into local glyptic production: with the exception of Sardis and Cappadocian Caesarea, few gems have turned up in excavations in Anatolia ${ }^{27}$. Noteworthy exceptions

${ }^{19}$ For example: Walters 1927, 178, n. 1654 (garnet); AGDS I,1, 106, nos. 624, 626, pl. 64 (cornelian, sardonyx).

${ }^{20}$ To cite just a few important gems: Walters 1927, 178, n. 1655 (amethyst); AGDS I,1, 106, n. 627, pl. 64 (cornelian).

${ }^{21}$ Different groups characterised by numerous variants have been identified: Fellmann Brogli 1996.

${ }^{22}$ Depicting two figures in front of the altar with Priapus: Konuk - Arslan 2000, 127, n. 103. One person sitting in front of a column with herm of Priapus: Laflı 2012, 151, n. 114; Lafl1 2015, 88, n. 31.

${ }^{23}$ Studies relating to the Vesuvius area have established that rings with gemstones occur in both rich and poor burials: d'Ambrosio - de Carolis 1997, 22, 107.

${ }^{24}$ On glyptic production in general: Tassinari 2008; in Turkey: Tassinari 2008, 280-281, 284-285; Weiss 2013.

${ }^{25}$ A very important example among several unpublished glyptic collections is the one kept in the $\mathrm{Mu}-$ seum of Anatolian Civilizations in Ankara: We are extremely grateful to Dr. Özcan Şimşek for giving me the opportunity to view the collection.

${ }^{26}$ For finds of clay sealings (Italian: cretula, pl. e) in Turkey, see Önal 2007; Doksanaltı - Sağlan 2008; Önal 2010; Önal 2011; Berges 2010; Sayar - Önal. We may hope that further research into this valuable material will lead to fresh insights into glyptic production: Dssa Nardelli would like to thank Prof. Mehmed Önal for his kind hospitality at Zeugma and for giving her the opportunity to view the extraordinary collection of cretule. As a point of interest, in Gaziantep she watched a skilled gemstone engraver carve stones found on the banks of the River Euphrates.

${ }^{27}$ A gold ring with carnelian intaglio, depicting the Dioscuri with Selene, was found at the propylaeum of Laodicea on the Lycus: Şimşek 2007, 136,137, n. 51h. An agate intaglio was found in a hoard discovered at Alexandria Troas: Esch - Martin 2008, 138,139, pl. 27,2. Two gems found in the residential area of Hierapolis of Phrygia are now kept at the Archaeological Museum of Denizli-Hierapolis: Nardelli 2019, 630-634. 
are the finds in the Hellenistic necropolis of Iasos, at Buldan, Magnesia and in the northern necropolis of Phrygian Hierapolis ${ }^{28}$.

The fragmentary condition of the Olba gem excludes a definitive identification, but for the moment the hypothesis that it depicts Priapus would appear valid. This judgement must remain provisional and may be disproved by new discoveries. As it stands, however, it provides an addition to our knowledge of ancient iconography. The discovery may indeed turn out to be a complementary analytic tool in future research, not only in the study of glyptic iconography but also as a means of learning more about the social history of an important province.

Although the fragmentary state of the Olba intaglio renders a definitive identification impossible, its discovery may nonetheless be regarded as a useful contribution to the study of Turkey's glyptic heritage. It should be noted, however, that research is still in its early stages and that further investigations may shed new light on gemstones kept in public and private collections in Turkey. In particular, new information stemming from the excavations at Olba will make it easier to establish the presence of engraved gems as well as trading and import movements.

\section{Bibliography}

AGDS I,1

AGDS I,2

AGDS I,3

AGDS IV

AGWien I

Anderson 2007

Berges 2010
E. Brandt, Antike Gemmen in deutschen Sammlungen I, Staatliche Münzsammlung München, 1, München 1968.

E. Brandt - E. Schmidt, Antike Gemmen in deutschen Sammlungen I, Staatliche Münzsammlung München, 2, München 1970.

E. Brandt - W. Gercke - A. Krug - E. Schmidt, Antike Gemmen in deutschen Sammlungen I, Staatliche Münzsammlung München, 3, München 1972.

M. Schlüter - G. Platz Horster - P. Zazoff, Antike Gemmen in deutschen Sammlungen IV, Hannover, Kestner Museum; Hamburg, Museum für Kunst und Gewerbe, Hamburg 1975.

E. Zwierlein-Diehl, Die antiken Gemmen des Kunsthistorischen Museums in Wien, I, Die Gemmen von der minoischen Zeit bis zur frühen römischen Kaiserzeit, München 1973.

T. Anderson, Preliminary osteo-archaeological investigation in the North Necropolis in: M. D’Andria - M. P. Caggia (eds.), Hierapolis di Frigia I. Le attività delle campagne di scavo e restauro 2000-2003, Istanbul 2007, 474-493.

D. Berges, Ein königlich-pergamenischer Beamter in Aizanoi?, in: K. Rheidt (ed.), Aizanoi und Anatolien, Mainz 2010, 38-43.

\footnotetext{
${ }^{28}$ A ring with plain bezel and one scarab have been found at Iasos: Berti 1993, 193. Two cameos came from necropoleis at Buldan and Magnesia respectively: Ceylan 2000, fig. 12; Bingöl - Bingöl 2003. The tomb of a Jewish family in the northern necropolis of Hierapolis of Phrygia yielded an amethyst: Anderson 2007, 476-484, fig. 13.
} 
Berti 1993

Bingöl 1999

Bingöl - Bingöl 2003

Ceci 1999

Ceylan 2000

d'Ambrosio - de Carolis 1997

della Ratta-Rinaldi 1995

Doksanaltı - Sağlan 2008

Erten 2017

Erten 2018

Erten 2019

Erten 2021

Erten - Akkuş Koçak 2019

Esch - Martin 2008

Fellmann Brogli 2006

Gesztelyi 2000

Henig 1990
F. Berti, Iasos di Caria, in: G. Pugliese Carratelli (ed.), Arslantepe Hierapolis, Iasos, Kyme. Scavi archeologici italiani in Turchia, Venezia 1993, 189-247.

I. Bingöl, Museum of Anatolian Civilizations. Ancient Jewellery, Ankara 1999.

I. Bingöl - O. Bingöl, Der Cameo aus Magnesia, Anadolu 25, 2003, 27-35.

F. Ceci, Il culto di Priapo, in: G. della Ratta-Rinaldi (ed.), "Il Maripara”. La statua di Priapo a Formello, Formello 1999, 16-19.

A. Ceylan, Scavi a Tripolis e nella necropoli di Buldan, in: M. D'Andria - F. Silvestrelli (ed.), [Ricerche archeologiche turche nella valle del Lykos], Lecce 2000, 69-81.

A. d'Ambrosio - E. de Carolis, I monili dall'area vesuviana, Roma 1997.

G. della Ratta-Rinaldi, La statua di Priapo, in: G. della Ratta-Rinaldi (ed.), "Il Maripara". La statua di Priapo a Formello, Formello 1995, 13-15.

E. M. Doksanaltı - S. Sağlan, A Group of seal impressions from Karaman Museum, Anadolu 34, 2008, 77-100.

E. Erten, Sikke Buluntuları Bağlamında Olba'da II. Constantinus Dönemi, Seleucia VII, 2017, 129-147.

E. Erten, Olba Akropolisi Kazılarından Yeni Babil Damga Mührü, Seleucia VIII, 2018, 49-68.

E. Erten, Olba Akropolis Kazılarından Cam Pendant, Olba 27, 2019, 331-344.

E. Erten, Kazı Verileri Işığında Olba'nın Erken Yerleşim Tarihi, Seleucia XI, 2021, 33-48.

E. Erten - E. Akkuş Koçak, Olba Kazılarından Hellenistik Dönem Cam Kaseleri, Seleucia IX, 2019, 43-63.

T. Esch - K. Martin, Ein Hortfund aus Alexandria Troas. Neue Hinweise zur späten Stadtgeschichte, in: E. Schwertheim (ed.), Studien zum antiken Kleinasien VI (Asia Minor Studien 55), Bonn 2008, 93 139.

R. Fellmann Brogli, Gemmen und Kameen mit ländlichen Kultszenen. Untersuchungen zur Glyptik der ausgehenden römischen Republik und der Kaiserzeit, Bern 2006.

T. Gesztelyi, Antike Gemmen im Ungarischen Nationalmuseum, Budapest 2000.

M. Henig, Ashmolean Museum, Oxford. The Content Family Collection of Ancient Cameos, Oxford 1990. 
Henig 1994

Henig 2007

Hoey Middleton 2001

Knight 1981

Konuk - Arslan 2000

Laflı 2012

Laflı 2015

Martini 1981

Nardelli 2019

Önal 2007

Önal 2010

Önal 2011

Sayar - Önal

Sena Chiesa 1966

Spier 1992

Şimşek 2007
M. Henig, Classical Gems. Ancient and Modern Intaglios and Cameos in the Fitzwilliam Museum, Cambridge 1994.

M. Henig, A Corpus of Roman Engraved Gemstones from British Sites, ${ }^{3}$ Oxford. 2007.

S. Hoey Middleton, Classical Engraved Gems from Turkey and Elsewhere. The Wright Collection (BAR, Int. SS. 957), Oxford 2001.

R. P. Knight, Il culto di Priapo e i suoi rapporti con la teologia mistica degli antichi con un saggio sul culto dei poteri generatori nel Medioevo, Roma 1981. [Italian translation of the 1786 edition.]

K. Konuk - M. Arslan, Ancient Gems and Finger Rings from Asia Minor. The Yüksel Erimtan Collection, Ankara 2000.

E. Laflı, İzmir Müzesi’ndeki Intaglio ve Cameo Örnekleri: Ön Değerlendirmeler, Journal of Archeology \& Art, Mayıs-Ağustos 140, 2012, 133-154.

E. Lafl, $\mathrm{Zu}$ den Gemmen aus den Museen von Izmir, in: E. Lafl1 - S. Patac1 (eds.), Recent Studies on the Archaeology of Anatolia (BAR Int. Serr. 2750), 2015, 81-93.

M. Maaskant - Kleibrink, Catalogue of the Engraved Gems in the Royal Coin Cabinet, The Greek, Etruscan and Roman Collections, The Hague 1978.

M. C. Martini, Introduzione, in: Knight 1981, 7-20.

B. Nardelli, Gemme in Zaccaria, in: A. Ruggiu (ed.), Hierapolis di Frigia XII. Le abitazioni dell'insula 104 a Hierapolis di Frigia, İstanbul 2019, 630-634.

M. Önal, Clay Seal Impressions of Zeugma/Zeugma Mühür Bask1ları, Ankara 2007.

M. Önal, Deities and Cultures Meet on the Seal Impressions in Zeugma, in: Bolletino di Archeologia Online, volume speciale: International Congress of Classical Archaeology: Meetings between Cultures in the Ancient Mediterranean, 2010, 25-53.

M. Önal, Die Tonbullae von Doliche, in: E. Winter (ed.), Von Kummuh nach Telouch. Historische und archäologische Untersuchungen in Kommagene (Asia Minor Studien 64), Bonn 2011, 247-283.

M. H. Sayar - M. Önal, Zeugma'da bulunan I. Antiochos-Herakles tokalaşma steli (in press).

G. Sena Chiesa, Gemme del Museo Nazionale di Aquileia, Padova 1966.

J. Spier, Ancient Gems and Finger rings (The J. P. Getty Museum), Malibu 1992.

C. Şimşek, Laodikeia (Laodikeia ad Lycum), İstanbul 2007. 
Tassinari 2008

Tassinari 2011

Walters 1927

Weiss 2013

G. Tassinari, La produzione glittica a Roma: la questione delle officine nel mondo romano in epoca imperiale, Rivista di Studi Liguri LXXIV, 2008, 251-318.

G. Tassinari, Le pubblicazioni di glittica (2007-2011): una guida critica, Aquileia Nostra LXXXII, 2011, 137-179.

H. B. Walters, Catalogue of Engraved Gems \& Cameos, Greek, Etruscan \& Roman in the British Museum, London 1927.

C. Weiss, Gemmenbilder der lydischen Artemis/Kore von Sardeis, in: G. Kökdemir (ed.), Orhan Bingöl'e 67. Yaş Armağanı - A Festschrift for Orhan Bingöl on the Occasion of his 67th Birthday, Ankara 2013, 667-675.

\section{Olba Akropolisi'nden Akik Taşından Priapos Betimli Bir Intaglio}

Özet

Mersin ili Silifke ilçesine bağlı Olba antik kentinde 2018 yılında yapılan kazılarda oyma tekniği ile yapılmış değerli bir yüzük taşı ele geçmiştir. Bu gem Olba akropolisinde yapılan kazılarda bir çocuk mezarının içinde bulunmuştur. Söz konusu yüzük taşının kırık halde ele geçmesi konuyu tam anlamıyla anlamayı zorlaştırmaktadır. Yüzük taşının üst kısmında tespit edilebilen izler burada Dionysos ile ilişkili dinsel betimlerde gördügüumüz bir figürü hatırlatmaktadır. Öte yandan figürde gözlemlenen bazı ayırtedici özellikler Priapos ile ilgili bir tasvirden de söz edilmesi gerektiğini göstermektedir. Yüzük taşı üzerinde betimlenen figürün kendinden emin bir biçimde tasarımı, ustaca modellenmiş vücut kısımları, özellikle dizlerde gözlemlenebilen klasik sitilin ustaca izleri ve ayakların küçük topaklarla basitleştirilmiş şekilde sunulması ile yakalanan biçimsel titizlikten yola çıkarak eseri İ.Ö. 2. yüzyıla tarihleyebiliriz.

Anahtar Sözcükler: Türkiye, Olba, Akropolis, oyma yüzük taşı, oyma, Priapos.

\section{A Sard Intaglio with a Depiction of Priapus from the Acropolis of Olba} Abstract

During the 2018 campaign at Olba (Silifke District of Mersin Turkey), a broken sard was recovered from a child's grave. Its fragmentary condition renders identification difficult. Markings at the top suggest that it might portray a figure associated with Dionysiac worship; however, the iconography fairly clearly suggests a representation of Priapus. The confident design and skilful modelling of the limbs, and the considerable formal rigour that combines classical style with a simplified rendering of the knees and feet characteristic of the Italic-Republican 'pellet style', allow the sard to be dated to the second century BC.

Keywords: Turkey, Olba, Acropolis, engraved gems, intaglio, Priapus. 


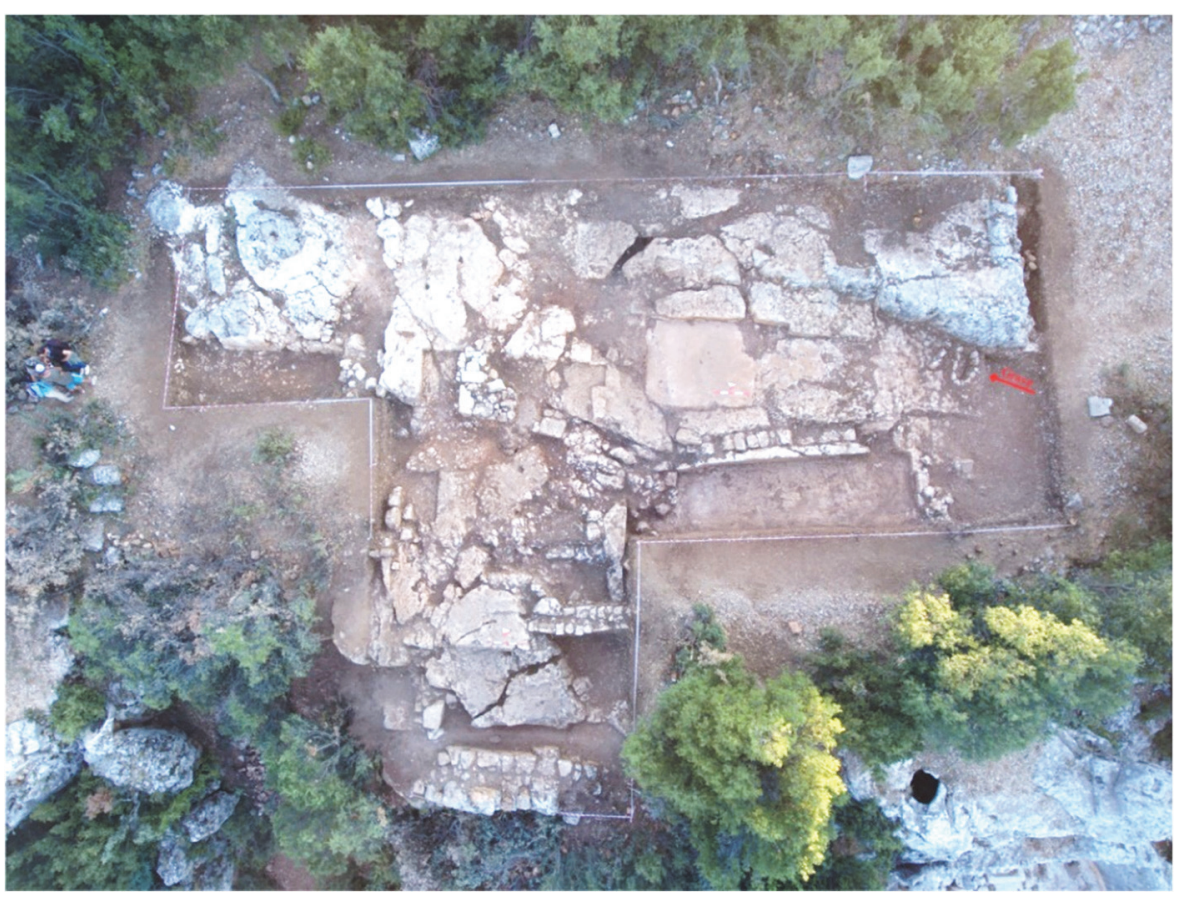

Fig 1) Akropolis and Grave
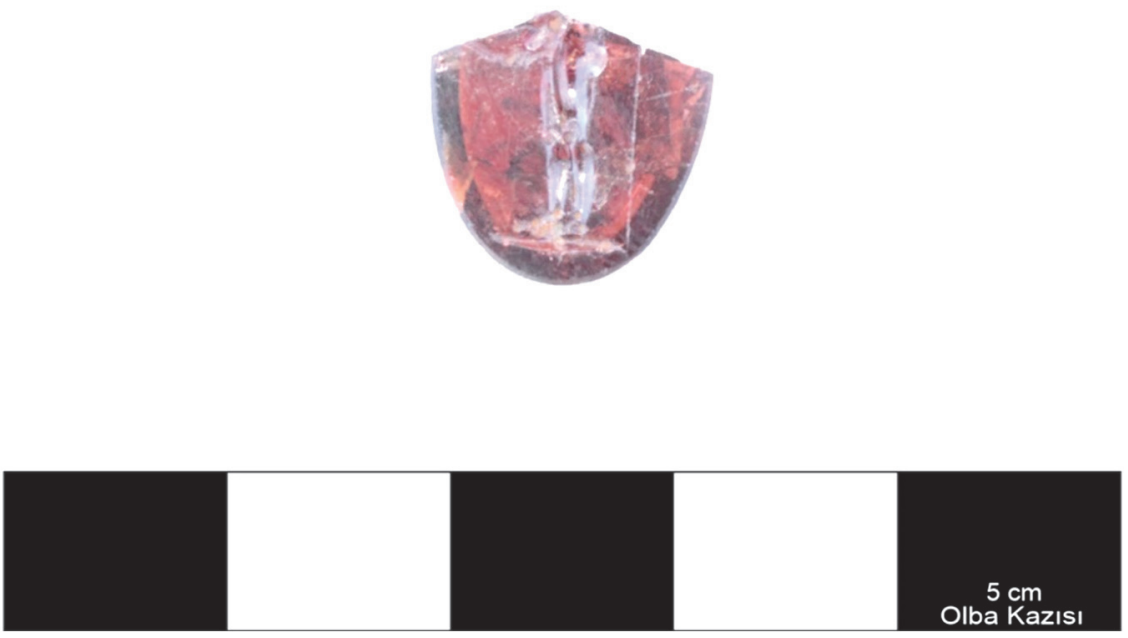

Fig 2) Obverse
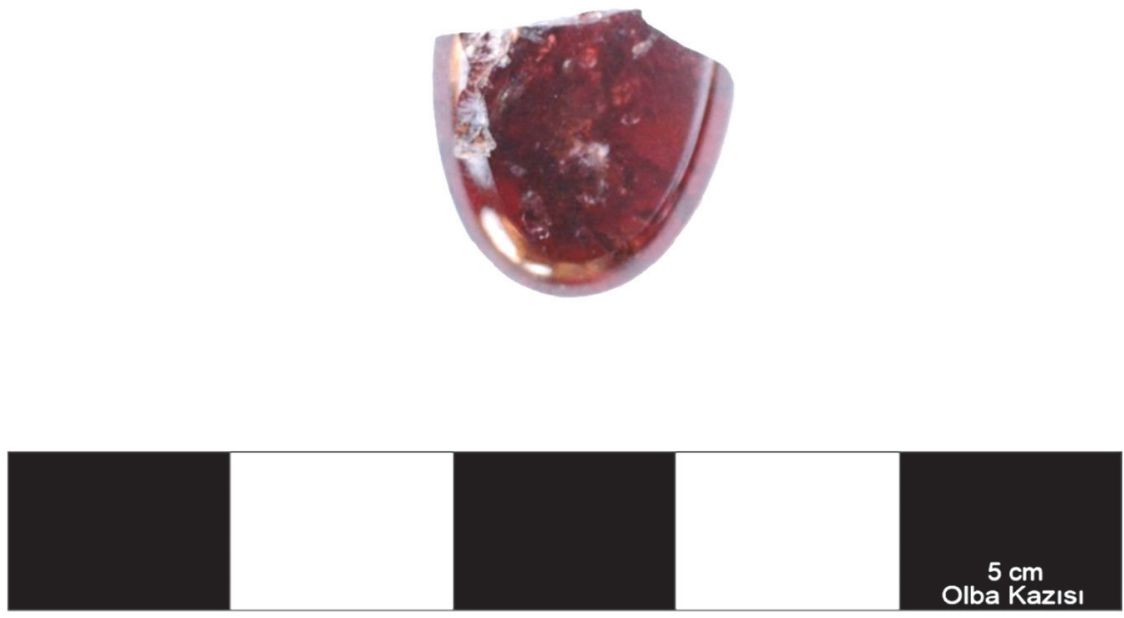

Fig 3) Reverse 


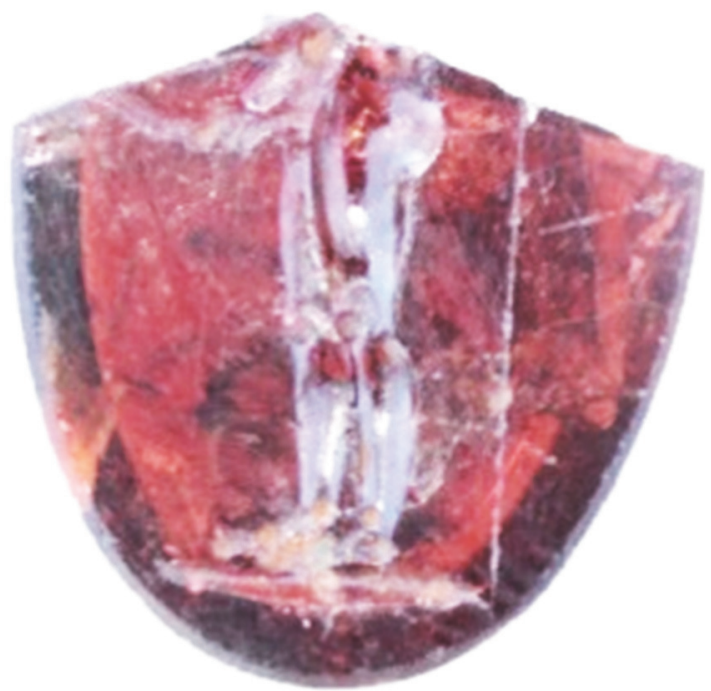

Obverse

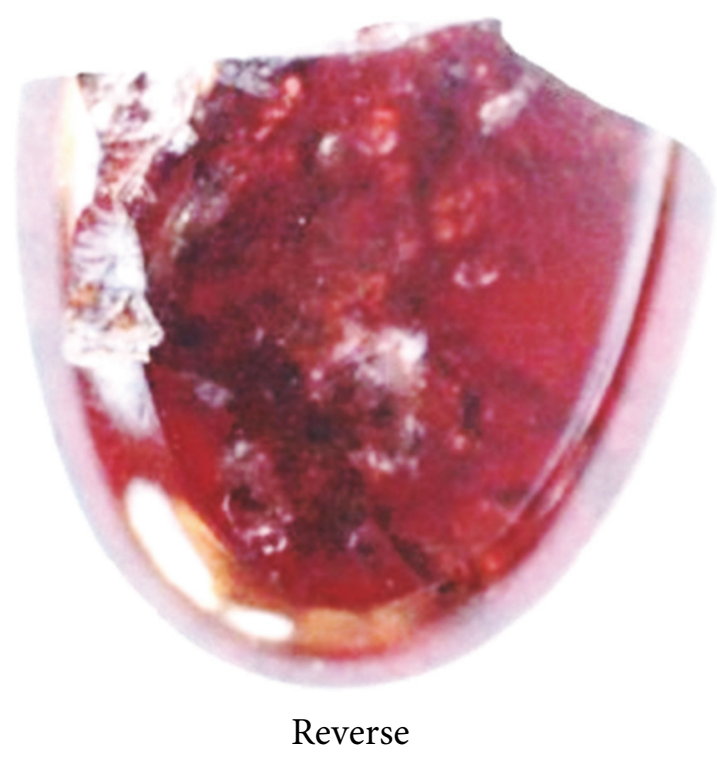

Reverse

Fig 4) Details of intaglio 